\title{
SORGHUM HYBRID CVSW 81198 AND ITS WEED COMMUNITY IN PERIODS WITH AND WITHOUT WEEDING
}

\author{
Paulo Roberto Fidelis Giancotti ${ }^{1}$, Mariluce Pascoina Nepomuceno², Matheus Sartori Moro², Anne Elise Cesarin², \\ Fernanda Nunes Bressanin², Pedro Luís da Costa Aguiar Alves² \\ ${ }^{1}$ Instituto Federal Farroupilha (IFFar) Panambi Campus, Rio Grande do Sul state, Brazil \\ ${ }^{2}$ Faculdade de Ciências Agrárias e Veterinárias - Universidade Estadual Paulista (FCAV - UNESP), Jaboticabal Campus, São Paulo \\ state, Brazil. \\ Autor para correspondência: Paulo Roberto Fidelis Giancotti, paulogiancotti@gmail.com
}

\begin{abstract}
The aim of this study was to evaluate the weed populations of sweet sorghum hybrid CVSW 81198 and its interference capacity in increasing periods with and without weeding. Two experiments were carried out, one during the summer and another during the autumn in the municipality of Jaboticabal, São Paulo state, Brazil. For each experiment, two treatment groups were established: one consisting of increasing periods without weeding and another of increasing periods with weeding. Periods were $0,4,7,14,21,28,35,42$ and 56 days after emergence (DAE) in the summer experiment and 0, 4, 7, 14, 21, 28, 35, 42, 49, 56, 63 and 100 DAE in the autumn experiment. Phytosociological studies of the weed community were carried out in each treatment, with emphasis on the importance index of each weed population. Under the experimental conditions, Amaranthus spp. and Alternanthera tenella were the most important species in the weed community of sweet sorghum grown during summer and autumn, respectively. With the natural infestation of the weed community, sorghum hybrid CVSW 81198 did not suffer interference in crop development and stem productivity even without weeding throughout the crop cycle.
\end{abstract}

KEY WORDS: Sorghum bicolor, weeds, interspecific interference, integrated management

\section{SORGO SACARINO CVSW 81198 E SUA COMUNIDADE INFESTANTE EM PERÍODOS COM E SEM CAPINA}

RESUMO: O presente estudo teve por objetivo avaliar as populações de plantas daninhas na cultura do sorgo sacarino, híbrido CVSW 81198 e sua capacidade de interferência em períodos crescentes com e sem capina. Foram conduzidos dois experimentos, um no verão e outro no outono, em Jaboticabal - SP, Brasil. Para cada experimento foram estabelecidos dois grupos de tratamentos: um consistiu em períodos crescentes sem capina de plantas daninhas e outro em períodos crescentes com capina. Os períodos foram $0,4,7,14,21,28,35,42$ e 56 dias a partir da emergência (DAE) no experimento de verão e de $0,4,7,14,21,28,35,42,49,56,63$ e 100 DAE no experimento de outono. Foram realizadas análises fitossociológicas da comunidade de plantas daninhas em cada tratamento, com destaque para o índice de importância de cada população daninha. Nas condições do experimento, as plantas daninhas Amaranthus spp. e Alternanthera tenella foram as mais importantes da comunidade infestante do sorgo sacarino cultivado no verão e no outono, respectivamente. Com a infestação natural da comunidade daninha, o híbrido de sorgo sacarino CVSW 81198 não sofreu interferência em desenvolvimento e produtividade de colmos pelas plantas daninhas mesmo quando não capinado durante todo o ciclo.

PALAVRAS CHAVE: Sorghum bicolor, plantas daninhas, interferência interespecífica, manejo integrado

\section{INTRODUCTION}

Since the oil crisis in the decade of 1970 s, the use of various raw materials for bioethanol production, such as sugarcane and alternative crops such as sorghum, has been studied in Brazil (Pereira Filho et al., 2013). Sorghum-energy can be classified into two types: sweet sorghum (for first-generation bioethanol) or biomass sorghum (for cogeneration from lignocellulosic biomass).
Weeds are a major problem for sorghum cultivation, as they can significantly reduce the production of grains, forage or ethanol, particularly when they coexist in the early stages of the crop (Santos et al., 2012; Silva et al., 2014). Maintaining a crop without weed control can lead to large losses. Reductions of 90,88 and $50 \%$ in the yield of grain, forage and sweet sorghum, respectively, have been reported (Rodrigues 
et al., 2010; Andres et al., 2009; Silva et al., 2014). Silva et al. (2014) consider the integrated weed management as one of the main bottlenecks in the production system, since control carried out at inappropriate time can increase production costs or lead to qualitative and quantitative yield losses. Compared to other economically important annual crops, there are few options for selective herbicides for sorghum crop, in addition to the atrazine molecule (Brazil, 2019).

In order to facilitate weed management, there are studies aimed at determining the critical periods of interference by the weed community in agricultural crops. These periods were defined by Pitelli and Durigan (1984) as the period before interference (PAI), total interference prevention period (PTPI) and critical interference prevention period (PCPI).

According to Pitelli (1985), the factors that can affect the degree of interference of the weed community on a crop depend on factors linked to weed (species, density and distribution) and to the crop itself (cultivar, spacing and sowing density). The degree of interference also depends on the period of coexistence of the weed community, the edaphoclimatic conditions and the management techniques used. For this reason, studies have been carried out with the most different ecological conditions, different cultivars, weeds and cultivation systems for greater robustness of agronomic recommendations (Carvalho and Velini, 2001).

Sorghum is a grass species with $\mathrm{C}_{4}$ photosynthetic metabolism known to present high conversion of solar energy into chemical energy (May, 2012). In addition, it has high allelopathic potential, rusticity and competitiveness, which can facilitate weed management in the field (Giancotti, 2017).

Therefore, weeds usually cause damage to agricultural crops, which can be minimized by using allelopathic and competitive crop, such as sweet sorghum. The present study aimed to evaluate weed populations infesting sweet sorghum hybrid CVSW 81198 and their interference in increasing periods with and without weeding.

\section{MATERIAL AND METHODS}

The study consisted of two field experiments sequentially conducted in the same experimental area, located at $21^{\circ} 15^{\prime} 02.1^{\prime \prime S}$ and $48^{\circ} 17^{\prime} 01.2^{\prime \prime} \mathrm{W}$ and $590 \mathrm{~m}$ a.s.I. in the municipality of Jaboticabal, SP, Brazil. Soil was classified as Dark Red Latosol with clayish texture and the chemical analysis of a field sample showed $\mathrm{pH}$ $\left(\mathrm{CaCl}_{2}\right)$ of $5.7 ; 40 \mathrm{~g} \mathrm{dm}^{-3}$ of organic matter; $73 \mathrm{mg} \mathrm{dm}^{-3}$ of $\mathrm{P}$ (resin); 3.8; 45; 18; 23; 51.8 and $89.8 \mathrm{mmolc} \mathrm{dm}^{-3}$ of $\mathrm{K}, \mathrm{Ca}, \mathrm{Mg}, \mathrm{H}+\mathrm{Al}, \mathrm{SB}$ and $\mathrm{CEC}$, respectively; and $\mathrm{V} \%$ of 69. Sweet sorghum was sown on December 5, 2012 (summer experiment) and on March 4, 2013 (autumn experiment), with fertilization carried out according to recommendation of Raij et al. (1997) for forage sorghum cultivation. For the autumn experiment, half the recommended fertilizer dose for forage sorghum was used in order to avoid the lodging phenomenon, which occurred during the first experiment (summer).

In both experiments, sweetsorghum hybrid CVSW 81198 provided by CanaVialis / Monsanto old company was used. The crop was sown in the summer experiment at spacing of $0.80 \mathrm{~m}$ between rows and 13 seeds $\mathrm{m}^{-1}$; and spacing of $0.90 \mathrm{~m}$ between rows and 8 seeds $\mathrm{m}^{-1}$, in the autumn experiment. Emergence occurred, mostly, six days after sowing. Twenty days after emergence in the summer experiment, nitrogen fertilization was carried out, with $110 \mathrm{~kg} \mathrm{ha}^{-1}$ of NPK 36-00-12 fertilizer; and for the autumn experiment, half of this dose was used.

Two treatment groups were established: one group consisted of increasing periods without weeding, and the other consisted of increasing periods with weeding. Periods were $0,4,7,14,21,28,35,42$ and 56 days after emergence (DAE) in the summer experiment and $0,4,7,14,21,28,35,42,49,56,63$ and $100 \mathrm{DAE}$ in the autumn experiment.

Each treatment had four replicates, with plots distributed in a randomized block design (RBD). Each plot was composed of 4 rows of 8 and $6 \mathrm{~m}$ in length for the summer and autumn experiments, respectively, corresponding to total area of 25.6 and $21.6 \mathrm{~m}^{2}$, respectively. Since lateral lines and the initial and final meters of each plot were discarded, the useful area was 12.8 and $10.8 \mathrm{~m}^{2}$ for the summer and autumn experiments, respectively.

Phytosociological indexes were determined during the increasing periods of coexistence of crop with weeds for both experiments (summer and autumn). The weed community was sampled using two $0.25 \mathrm{~m}^{2}$ sample randomly selected within the plot area. Shoots of weeds were collected, separated by species, dried in oven with forced air circulation at $65 \pm 2{ }^{\circ} \mathrm{C}$ until reaching constant dry mass and weighed in analytical scale (BEL $®$, accuracy of $0.0001 \mathrm{~g}$ ). The identification of species was based on morphological characteristics described in Lorenzi (2008). 
The phytosociological parameter known as relative importance index (RIm) was determined, which requires the determination of three other indexes: relative constancy ( $\mathrm{RCo})$, relative density $(\mathrm{RDe})$ and relative dominance (RDo). Phytosociology analysis followed methodology used by Barroso et al. (2012). RCo represents the recurrence of a species at different sampling points in a community. $\mathrm{RDe}$ was estimated with the number of individuals in a population in relation to the total number of individuals in a community. RDo represents the dry mass percentage accumulated by a species in relation to the dry mass of an entire weed community.

Diversity $(H$ ') and equitability ( $E$ ') indexes used by Bressanin et al. (2013) were also determined, where the $E$ 'index is the ratio of the $H$ ' index of a plant community in relation to the theoretical maximum $\mathrm{H}$ 'index, obtained when the evaluated factor was identical for all populations. $H$ 'and $E$ ' were calculated based on $\mathrm{RDe}, \mathrm{RDo}$ and RIm indexes.

In the summer experiment, sorghum plants showed vigorous growth, culminating in lodging at 68 DAE. On the same day, sorghum plants of the central meter of each plot were collected and dried to constant weightfordry mass determination. In the autumn experiment, crop was harvested at $100 \mathrm{DAE}$, when the yield of sweet sorghum stems was determined by the weight of stems present in the central two meters of the two central rows, totaling 4 $\mathrm{m}$ per plot. Weight was immediately obtained after cutting using portable scale with accuracy of $20 \mathrm{~g}$. Fresh weight (g plant ${ }^{-1}$ and tha ${ }^{-1}$ ), plant height (in meters, from the soil to the flag leaf) and stem diameter (in millimeters, $5 \mathrm{~cm}$ from the soil) were determined. During harvest, the Brix content of extreme treatments (all cultivation in the absence or presence of weeds) was measured to evaluate possible interference in this parameter.

Data were submitted to analysis of variance by the $\mathrm{F}$ test and means compared by the Tukey test at $5 \%$ probability using the Assistat v.7.6 beta software.

\section{RESULTS AND DISCUSSION}

\section{Experiment carried out in the summer}

During the phytosociological evaluations of weeds in the sweet sorghum culture, 22 weed species were found, belonging to 12 different families (Table 1). The family that presented the largest number of species was Convolvulaceae, with 6 species found. In the final evaluation, at $56 \mathrm{DAE}, 11$ species were sampled, with emphasis on Amaranthus spp., Commelina benghalensis L. and Digitaria nuda Schumach., which presented greater number and biomass.

Table 1. Weed species, organized by family, present during all phytosociological evaluations, in addition to the respective density and dry mass averages at 56 DAE of sweet sorghum hybrid CVSW 81198 cultivated in summer without weeding.

\begin{tabular}{|c|c|c|c|}
\hline Family & Scientific name & Density (plants $\mathrm{m}^{-2}$ ) & Dry mass $\left(\mathrm{g} \mathrm{m}^{-2}\right)$ \\
\hline \multirow{2}{*}{ Amaranthaceae } & Alternanthera tenella Colla & $-^{*}$ & - \\
\hline & Amaranthus spp. & 11.50 & 29.90 \\
\hline \multirow{3}{*}{ Asteraceae } & Parthenium hysterophorus L. & - & - \\
\hline & Acanthospermum hispidum DC. & 0.50 & 0.20 \\
\hline & Xanthium strumarium $\mathrm{L}$. & - & - \\
\hline Brassicaceae & Raphanus raphanistrum L. & 2.00 & 8.18 \\
\hline Commelinaceae & Commelina benghalensis $L$. & 8.50 & 10.60 \\
\hline \multirow{6}{*}{ Convolvulaceae } & Ipomoea hederifolia L. & 1.00 & 2.80 \\
\hline & Ipomoea nil (L.) Roth & - & - \\
\hline & Ipomoea purpurea (L.) Roth & - & - \\
\hline & Ipomoea quamoclit L. & - & - \\
\hline & Merremia aegyptia L. & - & - \\
\hline & Merremia cissoides (Lam.) Hall. & - & - \\
\hline Cyperaceae & Cyperus rotundus $L$. & 2.00 & 2.28 \\
\hline Fabaceae & Indigofera hirsuta L. & 1.00 & 0.46 \\
\hline Lamiaceae & Leonotis nepetiifolia (L.) R.Br. & - & - \\
\hline Malvaceae & Sida rhombifolia $L$. & - & - \\
\hline \multirow{3}{*}{ Poaceae } & Digitaria nuda Schumach. & 8.00 & 26.10 \\
\hline & Eleusine indica (L.) Gaertn. & 3.00 & 1.84 \\
\hline & Panicum maximum Jacq. & - & - \\
\hline Portulacaceae & Portulaca oleracea L. & 0.50 & 0.16 \\
\hline Phyllanthaceae & Phyllanthus tenellus Roxb. & 0.50 & 0.00 \\
\hline
\end{tabular}

${ }^{*}$ Weed found in weed community evaluations, but not during the evaluation of treatment without weeding until the end of the experiment at 56 DAE. 
At 4 DAE, no weeds were found in sorghum hybrid CVSW 81198 grown in the summer. Considering all evaluations carried out in this experiment, weeds that presented the highest RIm were Amaranthus spp.,
D. nuda and Raphanus raphanistrum L., respectively (Figure 1). However, the sum of RIm of the other less important weed populations was higher than the RIm of any population in all assessments.

Figure 1. Relative importance index (RIm) of weed populations during increasing periods without weeding in sweet sorghum hybrid CVSW 81198 crop grown in the summer.

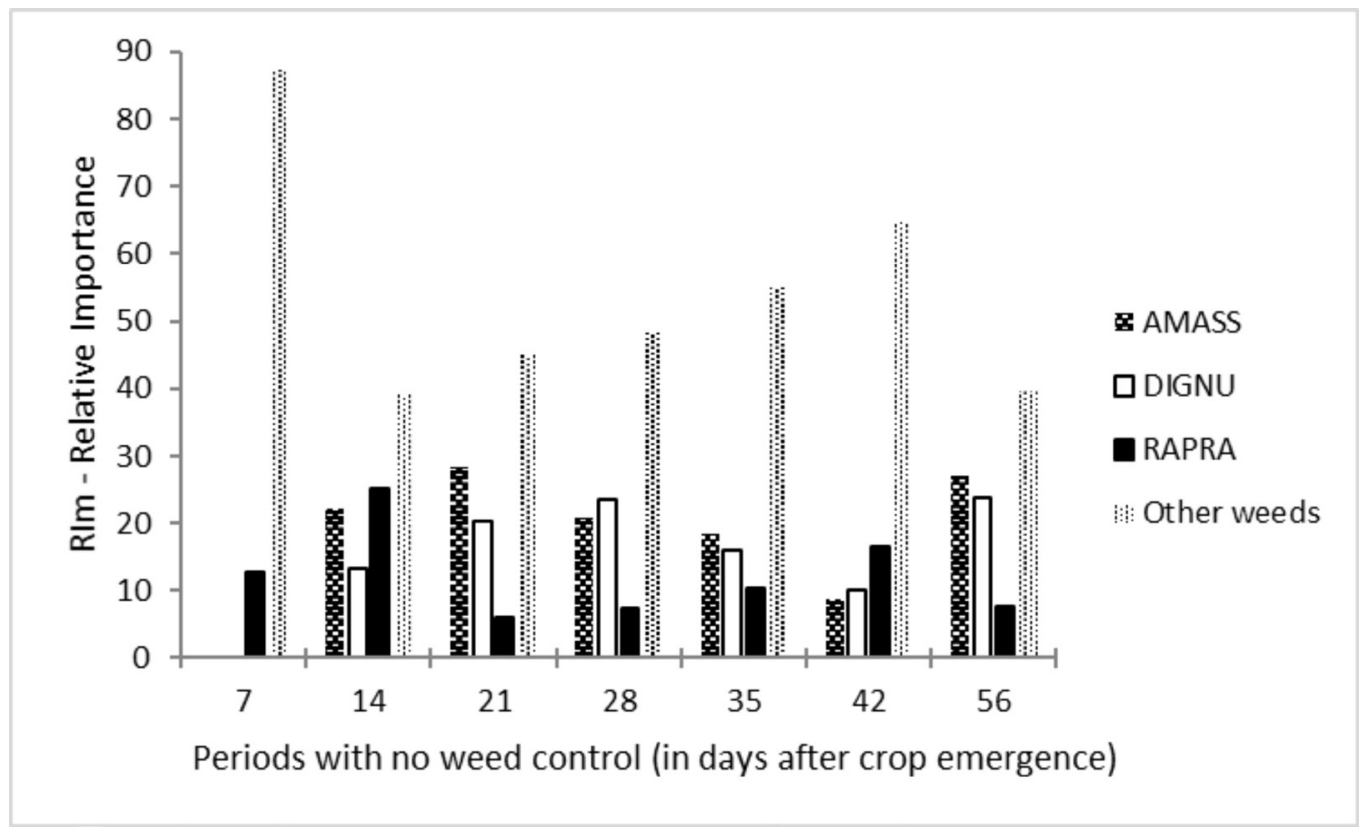

AMASS $=$ Amaranthus spp.$;$ DIGNU $=$ Digitaria nuda; RAPRA $=$ Raphanus raphanistrum.

The weed community diversity index considering the relative importance of populations $\left(\mathrm{H}^{\prime}\right.$ $\mathrm{R} / \mathrm{m}$ ) was lower at the beginning of the crop cycle at 7 DAE of crop submitted in increasing periods without weeding, with value of 1.11 , and higher at $42 \mathrm{DAE}$, with value of 2.46 (Figure $2 \mathrm{~A}$ ). H' RIm was similar to $\mathrm{H}^{\prime}$
RDe., which means that the importance of the species was more influenced by the number of individuals than the dry mass accumulation. In addition, there is greater diversity in the characteristic of plant density than in the characteristic of plant biomass for weed community populations.

Figure 2. Phytosociological diversity $\left(H^{\prime}\right)$ and equitability ( $\left.E^{\prime}\right)$ index of the weed community sampled in sweet sorghum hybrid CVSW 81198 cultivated during the summer and submitted to increasing periods without weeding. The relative density (RDe), relative dominancy (RDo) and relative importance (RIm) were used to determine H' and E'.

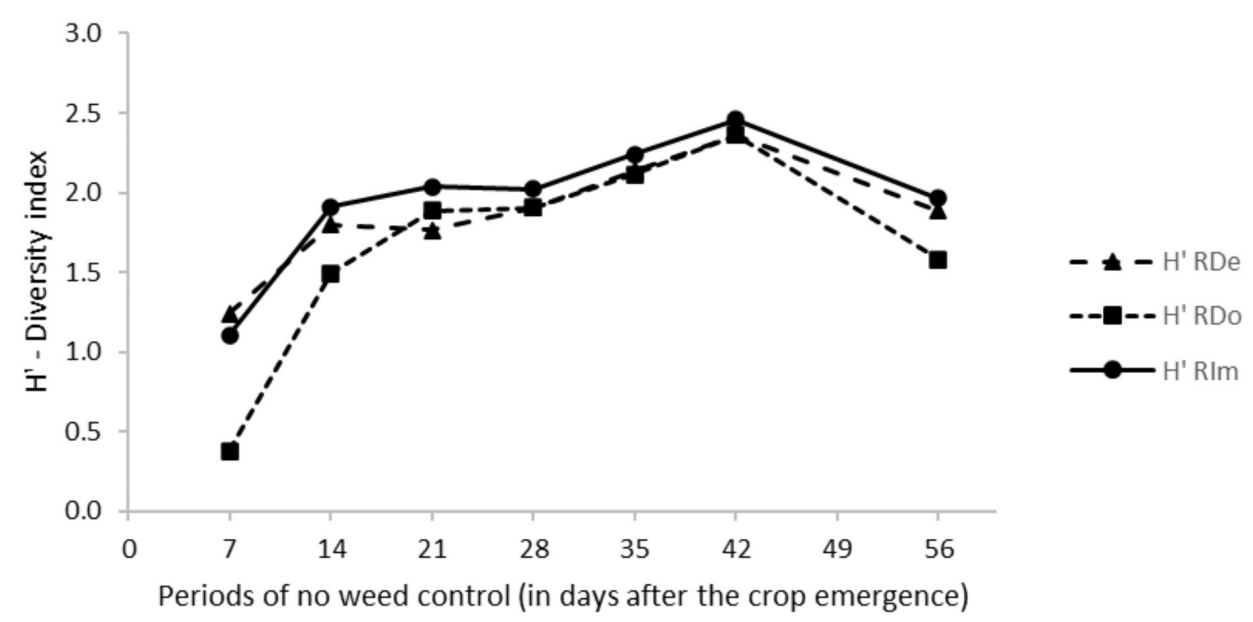




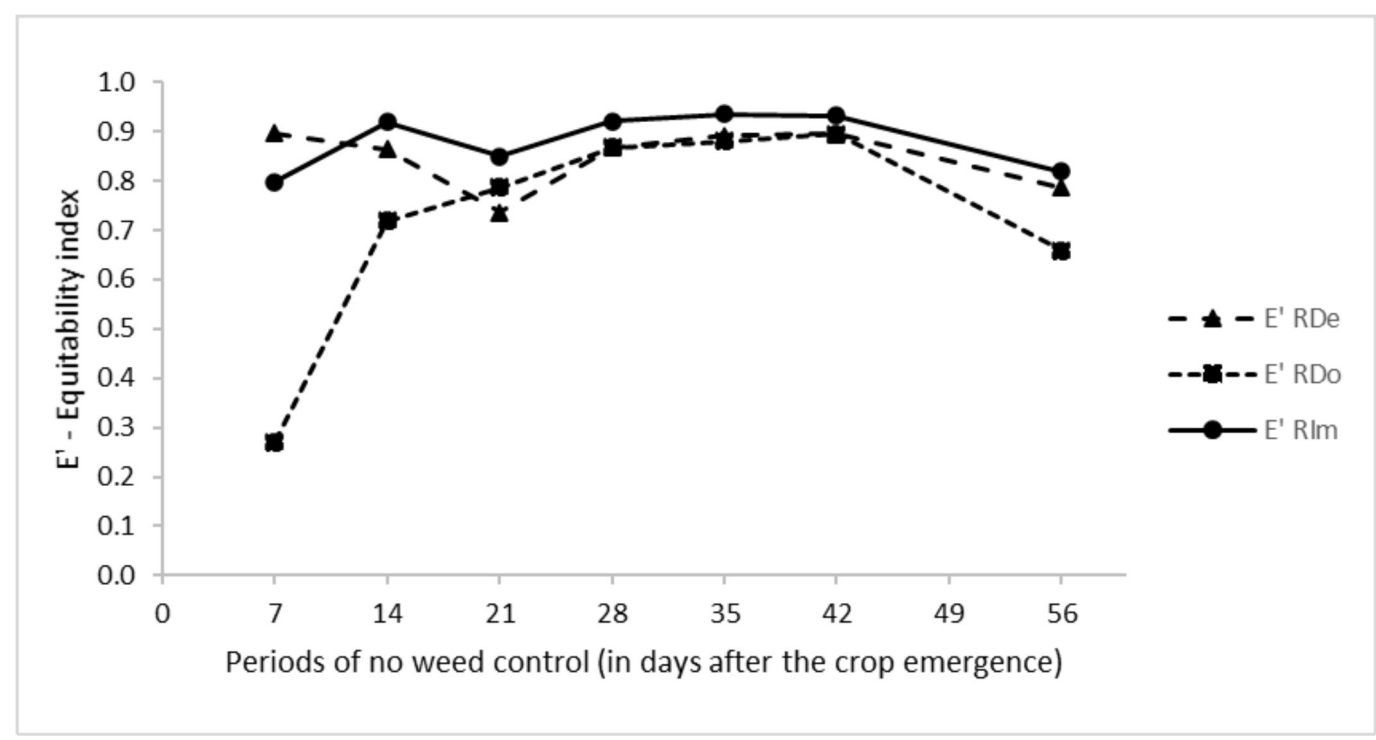

The equitability index that considers the relative importance of populations (E'RIm) was similar and high in all evaluations of the weed community in sorghum hybrid CVSW 81198 cultivated in the summer, submitted to increasing periods without weeding. E' RIm varied from 0.80 at 7 DAE to 0.94 , very close to the maximum value (1), at $35 \mathrm{DAE}$ (Figure $2 \mathrm{~B}$ ). This result demonstrates the uniformity of the importance of each species in the weed community throughout the crop development. At the beginning of sorghum crop development, weeds showed low equitability in relation to biomass, since the E' RDo. index was only 0.27 . This result indicates that few weed populations, in relation to the entire community, were more efficient in accumulating biomass at the beginning of the cycle, after soil turning and implantation of the sweet sorghum culture.

The increasing periods in which sweet sorghum hybrid CVSW 81198 cultivated in the summer did not have weeding did not influence the dry mass accumulation of shoots at 56 DAE (Table 2). Likewise, increasing weeding periods did not result in significant difference in crop biomass. Plant dry mass showed average values of $77.3 \mathrm{~g} \mathrm{plant}^{-1}$ and $11.5 \mathrm{t} \mathrm{ha}^{-1}$, at 56 DAE. Then, the conduction of the experiment was interrupted due to the lodging phenomenon.

Table 2. Dry mass of sweet sorghum hybrid CVSW 81198 cultivated in summer, submitted to increasing periods with and without weeding at 56 DAE.

\begin{tabular}{|c|c|c|}
\hline Crop DAE & (g plant $\left.^{-1}\right)$ & $\left(\mathrm{t} \mathrm{ha}^{-1}\right)$ \\
\hline \multicolumn{3}{|c|}{ Periods without weeding } \\
\hline 0 & 86.04 & 12.49 \\
\hline 4 & 65.13 & 9.83 \\
\hline 7 & 69.18 & 9.01 \\
\hline 14 & 67.18 & 10.36 \\
\hline 21 & 75.96 & 10.88 \\
\hline 28 & 81.63 & 10.54 \\
\hline 35 & 76.34 & 9.99 \\
\hline 42 & 82.86 & 12.05 \\
\hline 56 & 72.40 & 9.95 \\
\hline $\mathrm{F}$ & $0.55^{\mathrm{NS}}$ & $0.96^{\mathrm{NS}}$ \\
\hline CV $(\%)$ & 26.37 & 21.26 \\
\hline \multicolumn{3}{|c|}{ Periods with weeding } \\
\hline 0 & 83.88 & 12.78 \\
\hline 4 & 86.97 & 10.38 \\
\hline 7 & 79.33 & 11.92 \\
\hline 14 & 69.75 & 12.59 \\
\hline 21 & 81.03 & 12.39 \\
\hline 28 & 86.99 & 11.77 \\
\hline 35 & 72.23 & 13.53 \\
\hline 42 & 77.50 & 14.90 \\
\hline 56 & 77.56 & 12.00 \\
\hline $\mathrm{F}$ & $0.65^{\mathrm{NS}}$ & $1.12^{\mathrm{NS}}$ \\
\hline CV (\%) & 18.71 & 18.98 \\
\hline
\end{tabular}

\footnotetext{
${ }^{1}$ Days after emergence. ${ }^{\text {NS }}$ Not significant by the Tukey test $(p>0.05)$.
} 


\section{Experiment carried out in the autumn}

Twenty-one weed species belonging to 12 different families were found throughout phytosociological evaluations of the infestation community of sweet sorghum hybrid CVSW 81198 cultivated in the autumn (Table 3). In treatment in which the crop remained without weeding, Alternanthera tenella Colla weed was present in high density (24 plants $\left.\mathrm{m}^{-2}\right)$ and biomass $\left(209 \mathrm{~g} \mathrm{~m}^{-2}\right)$ in relation to the other species during harvest.

Table 3. Weed species, organized by family, present during all phytosociological assessments, in addition to their respective density and dry mass averages when sampled during harvest of sweet sorghum hybrid CVSW 81198, grown in the autumn without weeding.

\begin{tabular}{|c|c|c|c|}
\hline Family & Scientific name & Density (plants $\mathrm{m}^{-2}$ ) & Dry mass $\left(\mathrm{g} \mathrm{m}^{-2}\right)$ \\
\hline \multirow{3}{*}{ Amaranthaceae } & Alternanthera tenella Colla & 24.50 & 209.18 \\
\hline & Amaranthus spp. & $--^{*}$ & - \\
\hline & Emilia sonchifolia (L.) DC. & - & - \\
\hline \multirow{3}{*}{ Asteraceae } & Acanthospermum hispidum D.C. & 1.00 & 3.08 \\
\hline & Parthenium hysterophorus $\mathrm{L}$. & - & - \\
\hline & Xanthium strumarium L. & - & - \\
\hline Brassicaceae & Raphanus raphanistrum L. & - & - \\
\hline Commelinaceae & Commelina benghalensis $\mathrm{L}$. & 3.50 & 1.98 \\
\hline \multirow{2}{*}{ Convolvulaceae } & Ipomoea purpurea (L.) Roth & 0.50 & 0.11 \\
\hline & Merremia cissoides (Lam.) Hall. & - & - \\
\hline Cyperaceae & Cyperus rotundus L. & 3.50 & 1.98 \\
\hline \multirow{2}{*}{ Euphorbiaceae } & Ricinus communis $\mathrm{L}$. & - & - \\
\hline & Euphorbia heterophylla L. & - & \\
\hline \multirow{2}{*}{ Fabaceae } & Indigofera hirsuta L. & 3.00 & 4.23 \\
\hline & Mimosa pudica L. & 2.50 & 0.13 \\
\hline Lamiaceae & Leonotis nepetiifolia (L.) R.Br. & - & - \\
\hline \multirow[t]{2}{*}{ Phyllanthaceae } & Phyllanthus tenellus Roxb. & - & - \\
\hline & Digitaria nuda (Schumach.) & - & - \\
\hline \multirow[t]{2}{*}{ Poaceae } & Eleusine indica (L.) Gaertn. & - & - \\
\hline & Cenchrus echinatus L. & 2.00 & 1.31 \\
\hline
\end{tabular}

Portulacaceae

Portulaca oleracea L.

${ }^{*}$ Weed found in weed community evaluations, but not during the evaluation of treatment without weeding until the end of the experiment at $100 \mathrm{DAE}$.

No weeds were found in the 4 DAE period of sweet sorghum hybrid CVSW 81198 cultivated in the autumn. At the end of the increasing periods without weeding, populations with the highest $\mathrm{RIm}$ were $A$. tenella, Cenchrus echinatus L. and Portulaca oleracea $L$, with emphasis on the first, which only did not present the highest index at 7 DAE (Table $3 \mathrm{~A}$ ). A. tenella was the species with the highest RIm for all increasing weeding periods (Figure $3 \mathrm{~B}$ ). Acanthospermum hispidum $\mathrm{DC}$. and $\mathrm{C}$. echinatus presented the second and third highest RIm, considering all increasing weeding periods, followed by periods with no weeding.

The diversity and equitability indexes of the weed community of sweet sorghum hybrid CVSW 81198 grown in the autumn were slightly lower when compared to indexes found in the weed community of the crop grown in the summer (Figures 3, 4 and 5).

During increasing periods with and without weeding, the $\mathrm{H}$ 'and $\mathrm{E}$ ' indexes for RDe were more similar to RIm than indexes for RDo. (Figures 2, 4 and 5). Thus, it could be inferred that the RIm of populations was more affected by the number of individuals than by biomass accumulation.

During the increasing periods without weeding, followed by periods with weeding, the diversity index for relative importance ( $H^{\prime}$ RIm) was higher in the intermediate periods (21 to $63 \mathrm{DAE}$ ) and lower in the beginning (7 and $14 \mathrm{DAE}$ ) and final cycle (100 DAE) (Figure 4 A). Taking into account biomass (H' RDo and E' RDo), the species diversity and equitability indexes were more reduced, that is, few populations, especially $A$. tenella, were more effective in accumulating dry mass (Figure 4). 
Figure 3. Relative importance index (RIm) of weed populations during increasing periods without weeding $(A)$ and with weeding (B) in sweet sorghum hybrid CVSW cultivar 81198 grown in the autumn.
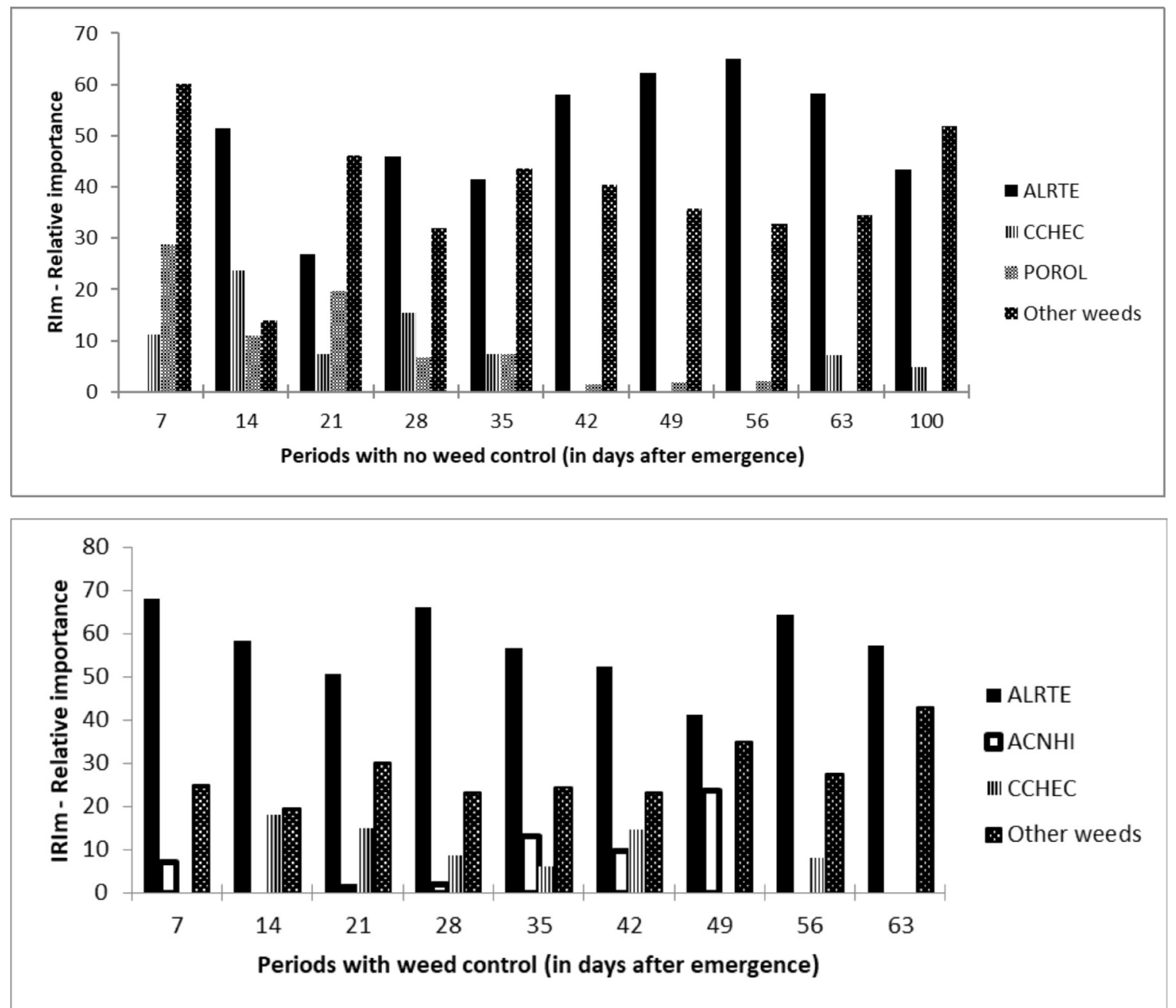

ALRTE $=$ Alternanthera tenella; $\mathrm{CCHEC}=$ Cenchrus echinatus; $\mathrm{POROL}=$ Portulaca oleracea; $\mathrm{ACHNI}=$ Acanthospermum hispidum.

Figure 4. Phytosociological diversity $\left(\mathrm{H}^{\prime}\right)(\mathrm{A})$ and equitability $\left(\mathrm{E}^{\prime}\right)$ indexes $(\mathrm{B})$ of the weed community sampled in sweet sorghum hybrid CVSW 81198 cultivated during autumn and submitted to increasing periods without weeding. The relative density $(R D e)$, relative dominancy $(R D)$ and relative importance (RIm) were used to determine H' and E'.

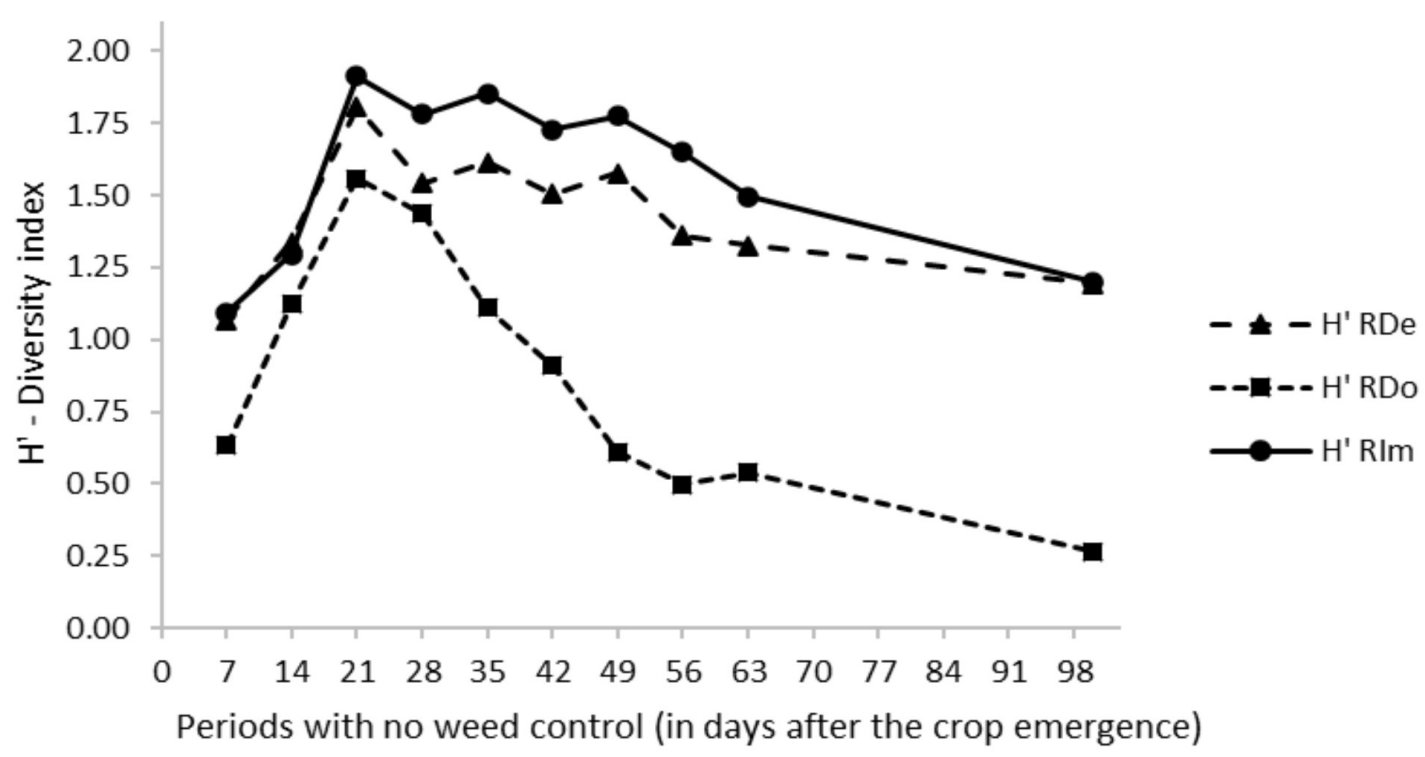




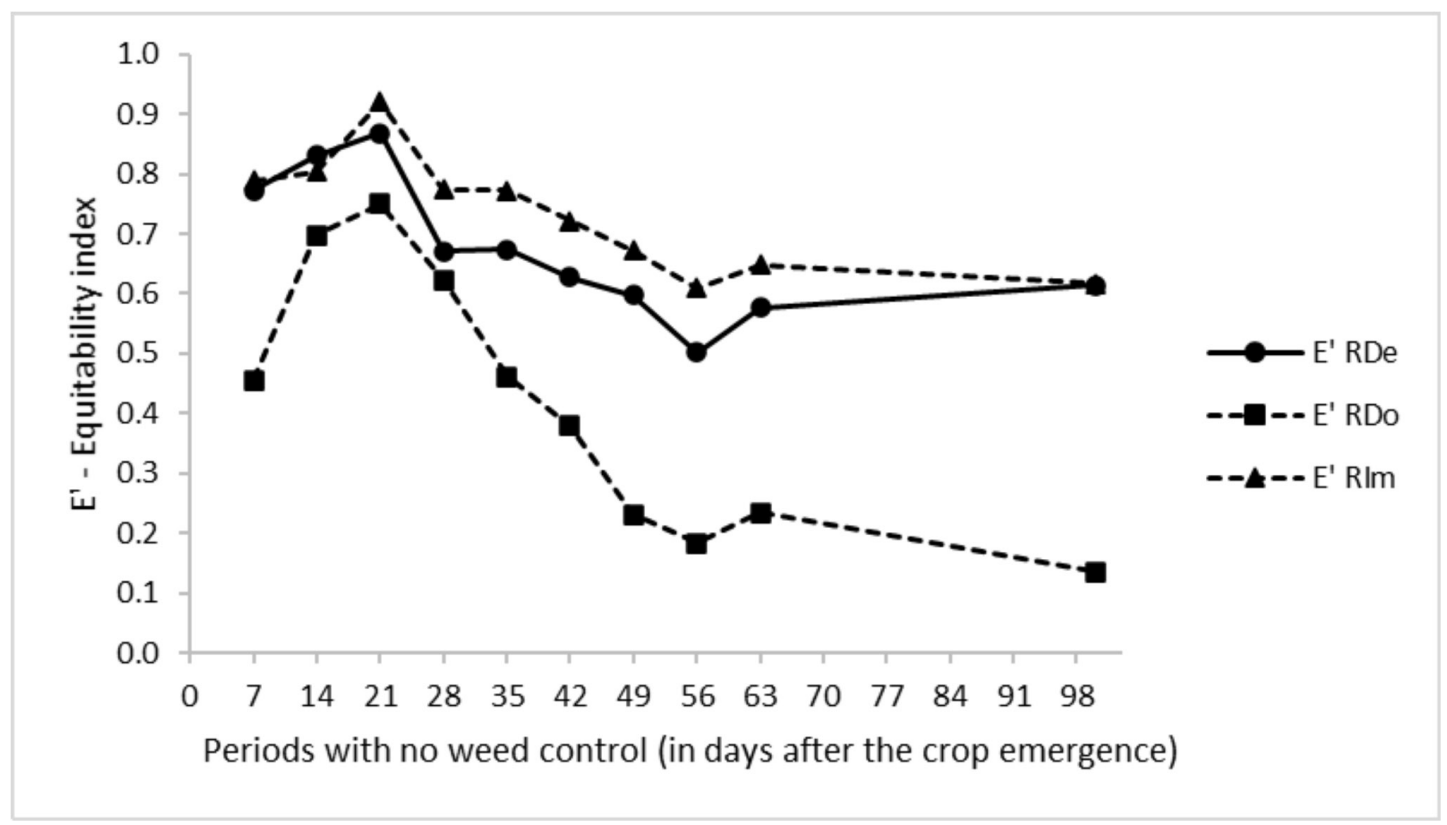

Figure 5. Phytosociological diversity $\left(H^{\prime}\right)(A)$ and equitability $\left(E^{\prime}\right)$ indexes $(B)$ of the weed community sampled in sweet sorghum hybrid CVSW 81198 cultivated during autumn and submitted to increasing periods with weeding. The relative density (RDe), relative dominancy (RDo) and relative importance (RIm) were used to determine H' and E'.
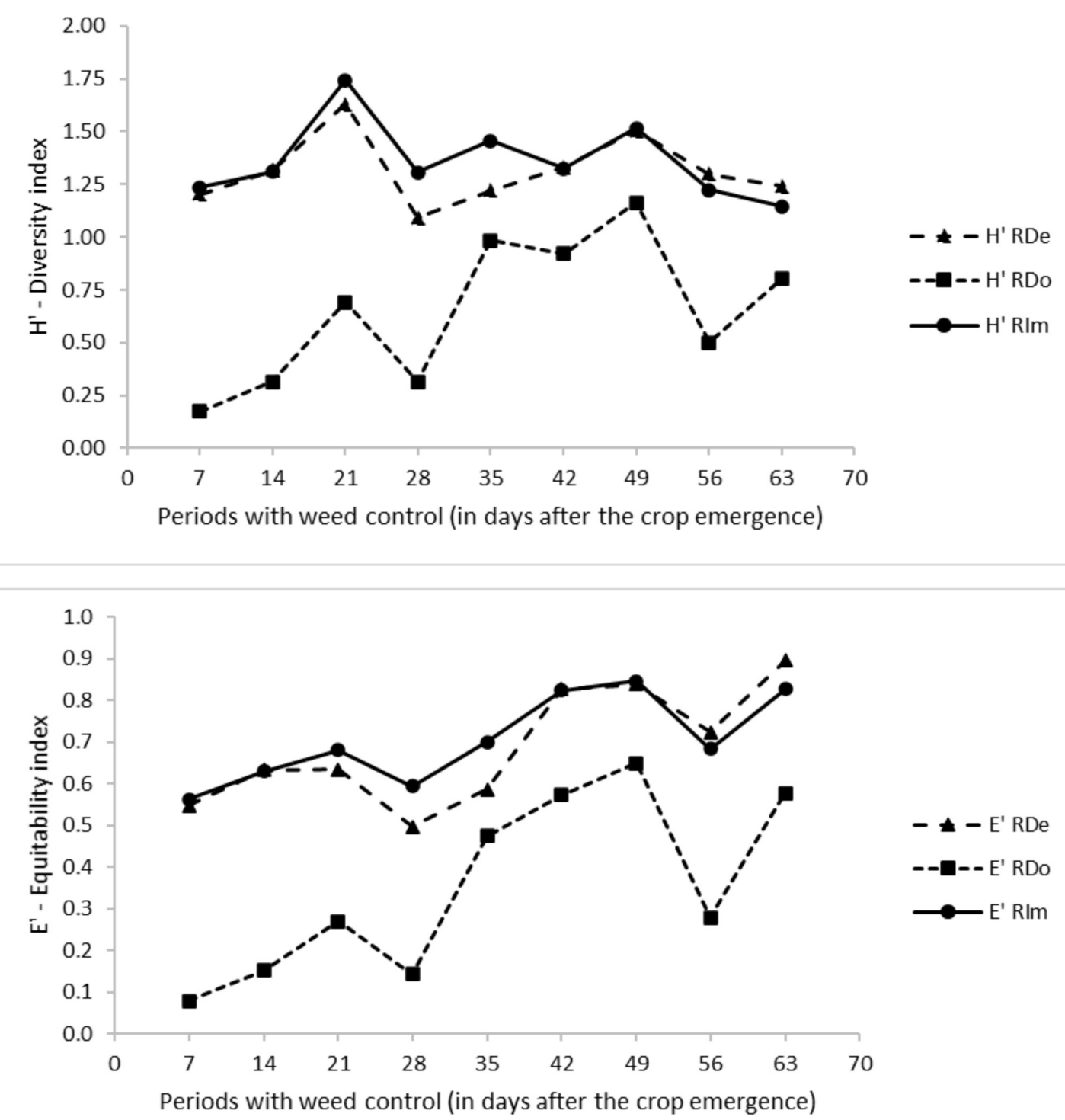
At the time of harvesting, no significant difference $\left(\mathrm{F}=1.45^{\mathrm{NS}}, \mathrm{CV}=25 \%\right.$ ) was observed in the amount of soluble solids (average of $15.02{ }^{\circ} \mathrm{Brix}$ ) between crops with and without weeding throughout the cycle.

All parameters evaluated (plant height, stem diameter, fresh mass per stem and stem productivity) during the harvest of sweet sorghum hybrid CVSW 81198 grown in the autumn did not show significant difference with increasing periods with or without weeding (Table 4). The average stem height and diameter was $2.42 \mathrm{~m}$ and 16.0 $\mathrm{mm}$, respectively. The average fresh stem mass and productivity was $339 \mathrm{~g} \mathrm{plant}^{-1}$ and $27.5 \mathrm{t} \mathrm{ha}^{-1}$, respectively.

Table 4. Plant height, stem diameter, fresh stem mass per plant and stem productivity during the harvest of sweet sorghum hybrid CVSW 81198 cultivated in autumn submitted to increasing periods with and without weeding.

\begin{tabular}{|c|c|c|c|c|}
\hline $\mathrm{DAE}^{1}$ & Plant height $(\mathrm{m})$ & Stem diameter $(\mathrm{mm})$ & Fresh stem mass (g plant $\left.{ }^{-1}\right)$ & Stem productivity $\left(\mathrm{t} \mathrm{ha}^{-1}\right)$ \\
\hline \multicolumn{5}{|c|}{ Periods without weeding } \\
\hline 0 & 2.41 & 15.70 & 331.77 & 28.65 \\
\hline 4 & 2.44 & 15.72 & 352.79 & 30.73 \\
\hline 7 & 2.43 & 15.80 & 353.70 & 25.43 \\
\hline 14 & 2.45 & 16.94 & 345.44 & 26.39 \\
\hline 21 & 2.41 & 15.92 & 344.20 & 25.99 \\
\hline 28 & 2.37 & 14.87 & 325.20 & 26.27 \\
\hline 35 & 2.45 & 15.20 & 337.07 & 26.03 \\
\hline 42 & 2.45 & 15.22 & 350.85 & 28.21 \\
\hline 56 & 2.40 & 15.87 & 326.53 & 27.22 \\
\hline 63 & 2.45 & 16.12 & 359.36 & 25.46 \\
\hline 100 & 2.43 & 16.16 & 319.93 & 25.67 \\
\hline $\mathrm{F}$ & $0.39^{N S}$ & $0.72^{\mathrm{NS}}$ & $0.62^{\mathrm{NS}}$ & $0.79^{\mathrm{NS}}$ \\
\hline CV $(\%)$ & 2.64 & 8.32 & 9.94 & 13.90 \\
\hline \multicolumn{5}{|c|}{ Periods with weeding } \\
\hline 0 & 2.43 & 16.15 & 319.93 & 25.67 \\
\hline 4 & 2.40 & 16.67 & 350.57 & 27.01 \\
\hline 7 & 2.46 & 16.30 & 344.76 & 29.77 \\
\hline 14 & 2.45 & 15.80 & 339.96 & 28.19 \\
\hline 21 & 2.40 & 16.34 & 336.85 & 26.39 \\
\hline 28 & 2.43 & 17.12 & 361.00 & 29.00 \\
\hline 35 & 2.42 & 15.71 & 326.89 & 27.34 \\
\hline 42 & 2.40 & 16.17 & 314.27 & 30.74 \\
\hline 56 & 2.41 & 16.25 & 322.36 & 28.94 \\
\hline 63 & 2.41 & 16.70 & 359.24 & 27.33 \\
\hline 100 & 2.41 & 15.70 & 331.77 & 28.65 \\
\hline $\mathrm{F}$ & $0.71^{\mathrm{NS}}$ & $0.68^{\mathrm{NS}}$ & $1.57^{\mathrm{NS}}$ & $0.81^{\mathrm{NS}}$ \\
\hline CV $(\%)$ & 2.91 & 6.64 & 7.46 & 11.96 \\
\hline
\end{tabular}

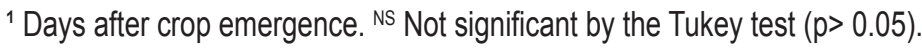

In the summer experiment, crop lodging occurred, a frequent phenomenon in sweet sorghum hybrids. According to May (2012), sweet sorghum cultivars are tall and excess grains in panicles, at the apex of plants, tends to favor lodging, which is undesirable because it reduces the quality of the raw material due to the higher content of impurities during harvesting. For new cultivars, studies are important to avoid lodging, as high nitrogen doses associated with high plant populations also favor this phenomenon. Evaluating sweet sorghum cultivars in southern
Brazil, Marchezan and Silva (1984) found lodging in sorghum plants with diameters ranging from $12.3 \mathrm{~mm}$ to $18.0 \mathrm{~mm}$.

The goals established by the "Embrapa Milho e Sorgo" breeding program assume that cultivars should have minimum stem productivity of $60 \mathrm{t} \mathrm{ha}^{-1}$ (May, 2012). However, an experiment conducted in the autumn, stem productivity was much lower, with average of $27.5 \mathrm{t} \mathrm{ha}^{-1}$. Also, according to May (2012), the delay in the planting season can lead to significant productivity losses due to water deficit 
and solar radiation limitations, leading to low stem productivity.

High RIm values (\%) indicate plants more adapted to the environment being evaluated, with large number of specimens and good distribution in the area, rapid initial growth, favoring the use of photosynthetically active radiation and consequently contributing to the suppression of neighboring species (Concenço et al., 2013). In experiment by Silva et al. (2014) conducted in the state of Mato Grosso, the phytosociological parameters of infesting species varied throughout the crop cycle, with Commelina benghalensis and Panicum maximum showing greater competitive ability than the other weeds, which was also observed in the present study, but with no significant importance.

In the summer experiment, species of the genus Amaranthus were those with the highest RIm. Among plant species of this genus, the following can be highlighted as the most common in Brazil, according to Carvalho et al. (2006): A. deflexus, A. hybridus, A. lividus, $A$. retroflexus, $A$. spinosus and $A$. viridis. The habit of aggressive growth and the prolific production of seeds provide Amaranthus spp. good competitiveness with crops for light, water and nutrients (Jha and Norsworthy, 2009). In the present study, these plants benefited from the period of rain and heat typical of summer, when they managed to emerge in density and accumulate biomass in an expressive way.

In the autumn experiment, the $A$. tenella population showed the highest $\mathrm{RIm}$. This is an important weed in agricultural systems due to its rapid spread and high infestation density, especially in the Cerrado region. A. tenella emerges in late summer and normally does not interfere with the initial crop growth (Canossa et al., 2008). This behavior was also observed in the present experiment, in which this weed species did not present RIm as expressive as in autumn, due to its seasonal growth habit. The same result was found for sweet sorghum hybrid CVSW 80007 in an experiment by Giancotti et al. (2017).

Rodrigues et al. (2010) studied the interference periods for grain sorghum and found a critical period of weed interference of four weeks. For Andres et al. (2009), under conditions of temperate climate and lowlands, the adequate period to carry out weed control in forage sorghum cultivation is between the emission of the third and the seventh leaf. Cabral et al. (2013), in research carried out with grain sorghum in the state of
Goiás, Brazil, found that the adequate period to carry out weed control is between the emission of the fifth and ninth leaf. Silva et al. (2014) studied sweet sorghum cultivar BRS 511 sown in early November, in the city of Sinop, MT, Brazil, reporting PTPI between the third and the eleventh fully expanded leaf (phenological stages V5 to V11) or 14 to 58 DAE. However, these results did not corroborate results of the present study, in which it was not possible to identify PCPI for the control of weeds, as there was no difference in the development of sweet sorghum hybrid 81198 submitted to weeding or not. Sweet sorghum hybrid CVSW 80007 has also been evaluated in increasing periods with or without weeding and no differences were found in the stem development and productivity (Giancotti et al., 2017), either in summer or in autumn. The different interference periods found reflect the different characteristics of cultivars, in addition to the conditions of crop implantation and management, edaphoclimatic conditions, and, mainly, to the composition and degree of the weed community infestation.

On a review on sweet sorghum crop, ZegadaLizarazu and Monti (2012) reported that the slow initial growth makes it susceptible to weed interference in the early stages of development, as weed presents rapid germination and emergence, quickly using environment resources. This fact implies that good crop management such as mechanical control or desiccation with herbicides is essential. Nevertheless, sweet sorghum presents natural tools that make it more tolerant to possible weed interference such as allelopathic potential and vigorous growth that develops soon after nitrogen fertilization. These facts, added to the characteristics of the local weed community, may explain the nonoccurrence of weed interference in sweet sorghum hybrid CVSW 91198 kept without weeding during the entire crop cycle. Sweet sorghum hybrid CVSW 80007 has also been evaluated in increasing periods with or without weeding and no differences in stem productivity were found (Giancotti et al., 2017).

It is known that sorghum produces a lipid compound called sorgoleone (2-hydroxy-5-methoxy-3[(Z,Z)-8',11', 14'-pentadecatriene] -p-benzoquinone), which is naturally released into the soil from root hair and, when in contact with weeds, inhibit their growth and development (Dayan et al., 2010). Allelopathy offers the possibility of performing biorrational control of weeds due to the production and release 
of allelochemical substances with biological activity (Jabran et al., 2015).

Under the experimental conditions, Amaranthus spp.e Alternanthera tenella were the most important in the weed community of sweet sorghum cultivated in summer and autumn, respectively. With the natural weed community that occurred in the experiments conducted in the summer and autumn, sweet sorghum hybrid CVSW 81198 did not suffer weed interference in stem development and productivity even without weeding throughout the cycle.

\section{ACKNOWLEDGMENTS}

To Capes (Coordination for the Improvement of Higher Education Personnel) and FAPESP (Research Support Foundation of the State of São Paulo) for providing the author with scholarships during certain periods as a doctoral student.

\section{REFERENCES}

Andres, A.; Concenço, G.; Scwanke, A. M. L.; Theisen, G.; Melo, P. T. B. S. Períodos de interferência de plantas daninhas na cultura do sorgo forrageiro em terras baixas. Planta Daninha, 2009, 27, 229-234.

Barroso, A. A. M.; Alves, P. L. C. A.; Yamauti, M. S.; Nepomuceno, M. P. Comunidade infestante e sua interferência no feijoeiro implantado sob plantio direto, na safra de primavera. Planta daninha, 2012, 30, 279-286.

Brasil. Ministério da Agricultura Pecuária e Abastecimento. AGROFIT. Disponível em: <http:// agrofit.agricultura.gov.br/agrofit_cons/principal_agrofit_ cons> Acesso em: 17 jan. 2019.

Bressanin, F. N.; Nepomuceno, M.; Martins, J. V. F.; Carvalho, L. B.; Alves, P. L. C. A. Influência da adubação nitrogenada sobre a interferência de plantas daninhas em feijoeiro. Revista Ceres, 2013, 60, 43-52.

Cabral, P. H. R.; Jakelaitis, A.; Cardoso, I. S.; Araújo, V. T.; Pedrini, E. C. F. Interferência de plantas daninhas na cultura do sorgo cultivado em safrinha. Pesquisa Agropecuária Tropical, 2013, 43, 308-314.

Canossa R. S.; Oliveira Jr., R. S.; Constantin, J.; Braccini, A. L.; Biffe, D. F.; Alonso, D. G.; Blainski, E.
Temperatura e luz na germinação das sementes de apaga-fogo (Alternanthera tenella). Planta Daninha, 2008, 26, 745-750.

Carvalho, F. T.; Velini, E. D. Períodos de interferência de plantas daninhas na cultura da soja. I - Cultivar IAC11. Planta Daninha, 2001, 19, 317-322.

Carvalho, S. J. P.; Buissa, J. A. R.; Nicolai, M.; LópezOvejero, R. F.; Christoffoleti, P. J. Suscetibilidade diferencial de plantas daninhas do gênero Amaranthus aos herbicidas trifloxysulfuron-sodium e chlorimuronethyl. Planta daninha, 2006, 24, 541-548.

Concenço, G; Ceccon, G.; Correia, I. V. T.; Leite, L. F.; Alves, V. B. Ocorrência de espécies daninhas em função de sucessões de cultivo. Planta Daninha, 2013, 31, 359-368.

Dayan, F. E; Rimando, A. M.; Pan, Zhiqiang, P.; Baerson, S. R. Gimsing, A. L.; Duke, S. O. Sorgoleone. Phytochemistry, 2010, 71, 1032-1039.

Giancotti, P.R.F.; Moro, M.S.; Nepomuceno, M.P.; Barroso, A.A.M.; Martins, P.F.R.B.; Alves, P.L.C.A. Weed community interference and phytosociological studies in a sweet sorghum crop. Planta Daninha, 2017, $35,1-10$.

Jabran, K.; Mahajan, G.; Sardana, V.; Chauhan, B. S. Crop Protection. 2015, 72, 57-65.

Jha, P.; Norsworthy, J. K. Soybean canopy and tillage effects on emergence of palmer amaranth (Amaranthus palmeri) from a natural seed bank. Weed Science. $2009,57,644-651$.

Lorenzi, H. Plantas daninhas do Brasil: terrestres, aquáticas, parasitas e tóxicas. $4^{\mathrm{a}}$. ed. Nova Odessa, SP: Instituto Plantarum, 2008, $640 \mathrm{p}$.

Marchezan, E.; Silva, M. I. Avaliação de cultivares de sorgo em Santa Maria, RS. Revista do Centro de Ciências Rurais, 1984, 14, 161-172.

May A. Sistema Embrapa de Produção Agroindustrial de Sorgo Sacarino para Bioetanol Sistema BRS1GTecnologia Qualidade Embrapa. Documentos 139. Embrapa Milho e Sorgo. Sete Lagoas, MG, 2012. 120 p. 
Pereira Filho, I.A.; Parrella, R.A.; Moreira, J.A.A.; May, A.; Souza, V.F.; Cruz, J.C. Avaliação de cultivares de sorgo sacarino [Sorghum bicolor (L.) MOENCH] em diferentes densidades de semeadura visando a características importantes na produção de etanol. Revista Brasileira de Milho e Sorgo, 2013, 12, 118-127.

Pitelli, R. A.; Durigan, J. C. Terminologia para períodos de controle e de convivência das plantas daninhas em culturas anuais e bianuais. In: Congresso Brasileiro de Herbicidas e Plantas Daninhas, 15., 1984, Belo Horizonte. Resumos... Piracicaba: SBHED, 1984. p.37.

Pitelli, R.A. Interferências de plantas daninhas em culturas agrícolas. In: Controle de Plantas Daninhas II. Informe Agropecuário, 1985, 11, 16- 27.

Raij, B. V.; Cantarella, H.; Quaggio, J. A.; Furlani, A. M. C. Editores. Recomendações de adubação e calagem para o Estado de São Paulo. $2^{\mathrm{a}}$ ed. Campinas: Instituto Agronômico/Fundação IAC, 1997. 285p. (Boletim Técnico, 100).
Rodrigues, A. C. P.; Costa, N. V.; Cardoso, L. A.; Campos, C. F.; Martins, D. Períodos de interferência de plantas daninhas na cultura do sorgo. Planta Daninha, 2010, 28, 23-31.

Santos, I. L. V. L.; Silva, C. R. C.; Santos, S. L.; Maia; M. M. D. Sorgoleone: benzoquinona lipídica de sorgo com efeitos alelopáticos na agricultura como herbicida. Arquivos do Instituto Biológico, 2012, 79, 135-144.

Silva, C.; Silva, A. F.; Vale, W. G.; Galon, L.; Petter, F. A.; May, A.; Karam, D. Interferência de plantas daninhas na cultura do sorgo sacarino. Bragantia, 2014, 73, 438445.

Zegada-Lizarazu, W.; Monti, A. Are we ready to cultivate sweet sorghum as a bioenergy feedstock? A review on field management practices. Biomass and Bioenergy, 2012, 40, 1-12. 